\title{
Research
}

\section{Integration of Local Ecological Knowledge and Conventional Science: a Study of Seven Community-Based Forestry Organizations in the USA}

\author{
$\underline{\text { Heidi L. Ballard }}^{1}, \underline{\text { Maria E. Fernandez-Gimenez }}^{2}$, and Victoria E. Sturtevant $^{3}$
}

\begin{abstract}
Natural resource management decisions can be based on incomplete knowledge when they lack scientific research, monitoring, and assessment and/or simultaneously fail to draw on local ecological knowledge. Many community-based forestry organizations in the United States attempt to address these knowledge gaps with an integrated ecological stewardship approach that balances ecological, social, and economic goals. This paper examines the use and integration of local knowledge and conventional science in ecological stewardship and monitoring by seven community-based forestry demonstration projects. Through document reviews and interviews with both participants and partners of all of these communitybased organizations, we found that all the community-based forestry groups incorporated local ecological knowledge into many aspects of their management or monitoring activities, such as collaboratively designing monitoring programs with local ranchers, forest workers, and residents; involving local people in collecting data and interpreting results; and documenting the local ecological knowledge of private forest landowners, long-time residents, and harvesters of nontimber forest products. We found that all the groups also used conventional science to design or conduct ecological assessments, monitoring, or research. We also found evidence, in the form of changes in attitudes on the part of local people and conventional scientists and jointly produced reports, that the two types of knowledge were integrated by all groups. These findings imply that community-based forestry groups are redistributing the power of conventional science through the use of diverse knowledge sources. Still, several obstacles prevented some local, traditionally underrepresented groups from being significantly involved in monitoring and management decisions, and their knowledge has not yet been consistently incorporated.
\end{abstract}

Key Words: civic science; community-based forestry; community-based natural resource management; conventional science; ecological assessment; ecological monitoring; local ecological knowledge; scientific knowledge

\section{INTRODUCTION}

In this paper, we examine the ways in which community-based forestry organizations (CBF groups) use and integrate local ecological knowledge (LEK) and conventional science in their forest management and monitoring activities on both private and public lands in the United States. Community-based forestry and other local approaches to natural resource management on these lands have become increasingly popular as the need to balance environmental, social, and economic goals becomes ever more pressing (Wondolleck and Yaffee 2000, Gray et al. 2001, Baker and Kusel 2003). Typically, large forestry institutions like the U.S. Forest Service, state forest agencies, and universities value scientific and technical expertise over the knowledge and experiences of local people. However, one of the primary characteristics of the community-based forestry approach that distinguishes it from more centralized, government-driven management is that people local to the resource participate directly or have a voice in stewardship activities (Wondolleck and Yaffee 2000, Gray et al. 2001, Borchers and Kusel 2003), including management, monitoring, and research.

Whereas this public participation can refer to decision making in land management, local people can also be involved in gathering ecological data that inform management via monitoring, research,

${ }^{1}$ University of California - Davis, ${ }^{2}$ Colorado State University, ${ }^{3}$ Southern Oregon University 
and other stewardship activities. Although the literature is replete with arguments for integrating the ecological knowledge of local people with conventional science to better achieve sustainable resource management and biodiversity conservation (Gadgil et al. 1993, Folke et al. 1998, Sillitoe 1998, Berkes et al. 2000, Pierotti and Wildcat 2000), it contains few examples of the process and little evidence of how these different types of knowledge are integrated (Mackinson 2001, Moller. et al. 2004, Gilchrist et al. 2005, Fernandez-Gimenez et al. 2006, Wilson et al. 2006). The work of CBF groups provides an opportunity to examine concrete cases involving the integration of LEK and conventional science on the ground. For the purposes of this paper, LEK refers to the local expertise of people who may not have a very long-term relationship with the local environment compared with indigenous people, but nevertheless have local wisdom, experience, and practices adapted to local ecosystems (Berkes and Folke 1998, Olsson and Folke 2001). In contrast, conventional science refers to science based on the traditions of Newtonian science and the expertise of government resource managers (Berkes et al. 2000).

Many studies have documented cases of local knowledge that has been incorporated into scientific studies, reflecting on the challenges this poses as well as the ways in which LEK enhanced research or management practices (Stevenson 1996, Calheiros et al. 2000, Huntington 2000, Usher 2000, Mackinson 2001, Ticktin and Johns 2002, Davis and Wagner 2003, Mallory et al. 2003, PattengillSemmens and Semmens 2003). Only a few researchers have analyzed the practices and strategies involved in integrating the two kinds of knowledge and made recommendations for future projects (Calheiros et al. 2000, Huntington 2000, Mackinson 2001, Klooster 2002, Davis and Wagner 2003, Ericksen and Woodley 2005, Schultz et al. 2007). Particularly rare are studies that examine attempts to integrate knowledge initiated by community groups rather than research scientists; we address this gap here. We developed our questions about the particular roles of local knowledge and conventional science in $\mathrm{CBF}$ groups, and how those roles are navigated by the organizations, from the literature and our earlier work with the CBF groups:

- How did CBF groups use LEK and conventional science in their management and monitoring activities?
- What is the evidence that $\mathrm{CBF}$ group management and monitoring activities integrated these different knowledge sources?

- What are the implications of these findings for other efforts to integrate LEK and conventional science to improve natural resource management?

In this paper, we first situate the discussion of $\mathrm{CBF}$ stewardship activities within the literature on the relationship between LEK and conventional science and the reasons for integrating knowledge. We then document the ways in which the CBF groups studied have intentionally sought out and incorporated LEK and knowledge holders, as well as conventional science and scientists, into their stewardship activities. We examine the evidence that $\mathrm{CBF}$ groups are integrating multiple types of knowledge into their activities by looking at (1) participant perspectives on the use and relevance of diverse knowledge types and (2) the products of this integration, such as reports that represent an interdependent combination of LEK and conventional science. Finally, we discuss the implications of the ways in which different kinds of knowledge were integrated into community-based forestry, including how these groups redistribute power by harnessing conventional science for their own use.

Recent debates about the political, scientific, and/ or ethical reasons for incorporating local knowledge into conventional science research continue: They range from simply seeking out and applying all reliable data sources (Gilchrist and Mallory 2007) to empowering communities (Brook and McLachlan 2005). Some authors propose that the interaction of LEK and conventional science is no less than an act of democratization of science (Shannon and Antypas 1996). In this way, what is called "civic science" is a restructuring of science toward public dialogue and participation and away from science as an objective enterprise carried out by scientists outside the system under study (Lee 1993, Shannon and Antypas 1996). Similarly, "community science" proposes an interaction of conventional and community-based scientific knowledge systems driven by community concerns rather than theory or basic research (Carr 2004). Incorporating components of all of these frameworks, we chose to examine the work of CBF groups through the lens of interdependent science, a term first used by Murphree (2004), who described it as "a set of 
knowledge-producing practices intended to provide better accounts of the world through collaboration between conventional and civil scientists." This requires new practices for the coproduction of knowledge (Ballard and Fortmann 2006). Our premise is that genuine knowledge integration, in contrast to co-optation, leads to an emergent whole that is greater than the sum of its parts. Because conventional science and LEK may each contribute different content and processes to forest management and monitoring, their integration represents a more comprehensive set of tools with which to manage resources. In our examination of CBF stewardship activities, we looked for evidence of the varying roles of local people and conventional scientists in directing and using the science produced.

The relationship between LEK and conventional science is also reflected in the question of whether LEK should be compared with or tested against conventional science measures (Brook and McLachlan 2005, Gilchrist and Mallory 2007). Researchers have used different terms to describe the interaction between LEK and conventional science: LEK is often described as a "complement," "supplement," "enhancement," or "expansion" of conventional science (Gadgil et al. 1993, Becker and Ostrom 1995, Johannes 1998, Berkes 1999, Scoones 1999, Colding and Folke 2001, Olsson and Folke 2001, Gilchrist et al. 2005). These terms reflect the primacy and power that conventional science holds in natural resource management and run the risk of relegating LEK to the role of a potentially unnecessary add-on or extension to the more important conventional science. In this paper, we do not compare LEK to conventional science or elevate one above the other, but instead examine how the CBF groups wrestling with these issues have chosen to combine LEK and conventional science. Conversely, many scholars and practitioners express concern that local people will be co-opted by scientists and managers; their knowledge may be highly valued but used inappropriately (Nadasdy 1999, 2003, Fernandez-Gimenez et al. 2006, Chalmers and Fabricius 2007). Therefore, we also looked for any evidence of co-optation in the CBF cases.

\section{METHODS}

\section{Sampling Frame and Study Sites}

The Ford Foundation Community-Forestry Demonstration Project funded 13 community-based forestry (CBF) groups for 5 years beginning in 1999. This network of organizations explicitly describes its approach as integrating social, economic, and ecological goals into stewardship and community development. In particular, several groups use an adaptive management approach that treats management actions as structured experiments and attempts to document and learn from both planned actions and unplanned environmental surprises (Holling 1978). In the last year of the program (2004), we were invited by the Ford Foundation to develop a research program based on the experiences of the 13 demonstration projects. One research theme was the role of $\mathrm{CBF}$ groups in ecological stewardship. Within the broader theme of stewardship, we focused on ecological assessment and monitoring because assessment is fundamental to natural resource planning and monitoring is essential to demonstrating short- and long-term environmental outcomes. Because of the short duration of the Ford program and the diversity of the funded groups and their environmental settings, we did not attempt to measure or make inferences about direct ecological impacts.

We purposely selected seven of the 13 funded groups for study based on each group's interest and willingness to participate in the research and its involvement in on-the-ground ecological stewardship, assessment, and monitoring activities. Five of the participating groups were located in the western USA and worked on public lands exclusively or on a mix of public and private lands. Two of the participating groups worked primarily with private landowners, one in the southeast region and one in the northeast region of the USA. The participating groups were:

- the Alliance of Forest Workers and Harvesters (AFWH), Willow Creek, California;

- the Federation of Southern Cooperatives Forest Legacy Program (FSC), Epps, Alabama;

- the Jobs and Biodiversity Coalition (JBC), Silver City, New Mexico; 
- the Public Lands Partnership (PLP), Delta, Colorado;

- Wallowa Resources (WR), Enterprise, Oregon;

- the Watershed Research and Training Center (WRTC), Hayfork, California; and

- Vermont Family Forests (VFF), Bristol, Vermont.

Table 1 provides a summary of each group's social and ecological setting, the ecological threats to the system, and the group's primary social and ecological objectives related to forest and rangeland stewardship.

Our research team used a modified participatory research approach, in that all of the 13 demonstration projects contributed to identifying key research questions and provided input and feedback on the research at key points throughout the process. On several occasions, this input took place at meetings or workshops at which the research team met directly with the leadership of all the $\mathrm{CBF}$ demonstration projects. Following the conclusion of most of the data collection and preliminary analysis, the research team convened a 3-day ground-truthing workshop, during which CBF group leadership helped validate and participated in the interpretation of our results.

\section{Data Collection and Analysis}

We collected data on the ecological stewardship, assessment, and monitoring activities of each group using a combination of on-site interviews and participant observation, telephone interviews, and a document review. We visited each group for a minimum of 3-5 days of interviews and field tours. Research questions were addressed through initial semistructured interviews with CBF staff, agency partners, community participants, and other potentially interested or involved organizations or individuals, e.g., environmental groups, industry representatives. We made additional multiple site visits to three of the study groups (AFWH, PLP, WRTC) as participant observers in monitoring or related stewardship activities. After completing our initial analyses, we conducted additional interviews to seek potentially contradictory evidence and substantiate or reject our initial findings. In all, we conducted formal interviews with 67 individuals in the seven groups. The documents reviewed included project proposals, internal reports, and reports to the Ford Foundation; ecological assessment and monitoring project protocols; interim and final reports and meeting minutes; public presentations by $\mathrm{CBF}$ groups about their stewardship and monitoring projects, e.g., PowerPoint slides and digital files from workshops; and existing case studies of the study organizations.

Formal interviews were audiorecorded, transcribed, and coded using QSR N*VIVO software (QSR International, Melbourne, Australia). Codes addressed descriptive research questions, e.g., CBF ecological stewardship objectives, strategies, and outcomes, and evidence related to our propositions, e.g., the use and integration of LEK and conventional science into community-based forestry. For our analysis we identified two primary indicators as evidence of knowledge integration. The first was discussion by local knowledge holders and conventional scientists of the value and usefulness of the alternative type of knowledge, which was supported by Castillo et al. (2005) and Fernandez-Gimenez et al. (2006), who found an important link between the attitudes and values of local and conventional science knowledge holders and the effective integration of knowledge for resource management. The second was concrete products such as documents or implemented projects that combine LEK and conventional science and are used by both types of knowledge holders. The resulting coding reports were synthesized within and across $\mathrm{CBF}$ groups to assess the evidence in relation to our propositions and identify emergent themes in the data.

\section{RESULTS}

\section{Using local ecological knowledge}

Among the seven CBF groups studied, we identified 24 projects specifically focused on ecological stewardship. This included all of the stages of the stewardship process: scoping, assessment and planning, implementation of management, and monitoring and evaluation. The CBF groups had various reasons for including different types of knowledge in their stewardship work, including the desire to have more complete information about natural resources and empower local people. For example, the PLP felt that the people holding 
Table 1. Overview of the ecological and social settings and objectives of the seven community-based forestry groups studied.

\begin{tabular}{|c|c|c|c|c|c|}
\hline Organization & Ecological setting & Ecological threats & Ecological goals & Social setting & Social goals \\
\hline AFHW & $\begin{array}{l}\text { Northwestern mixed } \\
\text { conifer forests to } \\
\text { California mixed } \\
\text { conifer to oak } \\
\text { savanna }\end{array}$ & $\begin{array}{l}\text { Invasive non- } \\
\text { native species } \\
\text { Altered fire } \\
\text { regimes } \\
\text { Degradation }\end{array}$ & $\begin{array}{l}\text { Reduce risk of } \\
\text { catastrophic fire } \\
\text { Restore the link } \\
\text { between livelihoods } \\
\text { and the forest } \\
\text { Protect resources } \\
\text { (mushrooms, basket } \\
\text { material) } \\
\text { Reduce herbicide } \\
\text { use }\end{array}$ & $\begin{array}{l}\text { Culturally diverse, } \\
\text { underserved com- } \\
\text { munity } \\
\text { Distrust among } \\
\text { harvester groups } \\
\text { and between } \\
\text { harvesters and } \\
\text { agencies } \\
\text { Invisible and } \\
\text { undervalued workers }\end{array}$ & $\begin{array}{l}\text { Social justice } \\
\text { Pay scale that } \\
\text { acknowledges skill } \\
\text { and work } \\
\text { Training }\end{array}$ \\
\hline FSC & $\begin{array}{l}\text { Southern pine and } \\
\text { hardwood forests } \\
\text { and associated } \\
\text { pasture and } \\
\text { farmland }\end{array}$ & $\begin{array}{l}\text { Land conversion } \\
\text { Habitat loss and } \\
\text { fragmentation } \\
\text { Poor logging and } \\
\text { reforestation practices }\end{array}$ & $\begin{array}{l}\text { Reduce land } \\
\text { conversion } \\
\text { Promote forest } \\
\text { stewardship }\end{array}$ & $\begin{array}{l}\text { Underserved com- } \\
\text { munity } \\
\text { Institutionalized } \\
\text { racism } \\
\text { State agency focus } \\
\text { on larger land } \\
\text { owners } \\
\text { Regulations disad- } \\
\text { vantage small } \\
\text { farmers } \\
\text { Distrust } \\
\text { Land retention } \\
\text { difficulties for } \\
\text { black families } \\
\text { Disconnect from } \\
\text { land }\end{array}$ & $\begin{array}{l}\text { Promote hands-on } \\
\text { learning } \\
\text { Network building } \\
\text { Advocacy } \\
\text { Outreach } \\
\text { Build ties to land }\end{array}$ \\
\hline $\mathrm{JBC}$ & $\begin{array}{l}\text { Southwestern pon- } \\
\text { derosa pine forests }\end{array}$ & $\begin{array}{l}\text { Altered fire } \\
\text { regimes } \\
\text { Poor logging } \\
\text { practices }\end{array}$ & $\begin{array}{l}\text { Achieve historic } \\
\text { ponderosa pine } \\
\text { forest structure and } \\
\text { function through } \\
\text { restoration rather } \\
\text { than "standard" } \\
\text { fuel reduction } \\
\text { Create wildlife } \\
\text { habitat }\end{array}$ & $\begin{array}{l}\text { Low socioeconomic } \\
\text { levels } \\
\text { Job loss because of } \\
\text { loss of timber on } \\
\text { federal lands and } \\
\text { mine closures } \\
\text { Anglo, Hispanic, } \\
\text { Mexican-American, } \\
\text { and Native } \\
\text { American }\end{array}$ & $\begin{array}{l}\text { Build trust and } \\
\text { support from } \\
\text { environmental org- } \\
\text { anizations and U.S. } \\
\text { Forest Service for } \\
\text { forest restoration } \\
\text { prescriptions } \\
\text { Create jobs that use } \\
\text { small-diameter wood } \\
\text { Reduce conflict }\end{array}$ \\
\hline
\end{tabular}




\begin{tabular}{|c|c|c|c|c|c|}
\hline PLP & $\begin{array}{l}\text { Western conifer } \\
\text { forests } \\
\text { Piñon-juniper wo- } \\
\text { odlands } \\
\text { Sagebrush-grassland } \\
\text { rangelands }\end{array}$ & $\begin{array}{l}\text { Altered fire } \\
\text { regimes } \\
\text { Non-native invasive } \\
\text { species } \\
\text { Habitat loss and } \\
\text { fragmentation } \\
\text { Erosion }\end{array}$ & $\begin{array}{l}\text { Enhance and } \\
\text { maintain diverse, } \\
\text { healthy, and viable } \\
\text { environments } \\
\text { Restore the link } \\
\text { between livelihoods } \\
\text { and the land }\end{array}$ & $\begin{array}{l}\text { Rapid demographic } \\
\text { change and } \\
\text { growth, with } \\
\text { increase in retirees, } \\
\text { amenity residents, } \\
\text { tourism, and } \\
\text { exurban development } \\
\text { Decline in } \\
\text { economic viability } \\
\text { of land-based } \\
\text { livelihoods } \\
\text { Growing Hispanic } \\
\text { population }\end{array}$ & $\begin{array}{l}\text { Facilitate constructive } \\
\text { dialogue about } \\
\text { public land } \\
\text { management } \\
\text { Participate in } \\
\text { public land } \\
\text { management decision } \\
\text { making } \\
\text { Increase awareness } \\
\text { of interdependence } \\
\text { of local economies } \\
\text { and landscapes } \\
\text { Increase civic } \\
\text { engagement and } \\
\text { social learning }\end{array}$ \\
\hline WR & $\begin{array}{l}\text { Western conifer } \\
\text { forests } \\
\text { Riparian habitat } \\
\text { Palouse prairie } \\
\text { rangelands }\end{array}$ & $\begin{array}{l}\text { Altered fire and } \\
\text { flood regimes } \\
\text { Non-native invasive } \\
\text { species } \\
\text { Habitat loss and } \\
\text { degradation } \\
\text { Fragmentation. }\end{array}$ & $\begin{array}{l}\text { Understand and } \\
\text { maintain natural } \\
\text { variation } \\
\text { Address causes as } \\
\text { well as symptoms } \\
\text { of degradation } \\
\text { Use adaptive } \\
\text { management } \\
\text { Restore the link } \\
\text { between livelihoods } \\
\text { and the forest }\end{array}$ & $\begin{array}{l}\text { Community in } \\
\text { transition because } \\
\text { of changing forest } \\
\text { policy, timber } \\
\text { industry restructuring, } \\
\text { and demographic } \\
\text { change } \\
\text { Increasing poverty } \\
\text { Declining institutional } \\
\text { capacity } \\
\text { Primarily Anglo }\end{array}$ & $\begin{array}{l}\text { Build trust and } \\
\text { support in } \\
\text { community and U. } \\
\text { S. Forest Service } \\
\text { for forest } \\
\text { restoration prescri- } \\
\text { ptions } \\
\text { Build trust and } \\
\text { reduce conflict } \\
\text { about management } \\
\text { Training, education, } \\
\text { and outreach } \\
\text { Build contractor } \\
\text { capacity and create } \\
\text { jobs }\end{array}$ \\
\hline WRTC & $\begin{array}{l}\text { California mixed } \\
\text { conifer forests, } \\
\text { with some } \\
\text { Ponderosa pine } \\
\text { Oak savannas and } \\
\text { early successional } \\
\text { shrublands }\end{array}$ & $\begin{array}{l}\text { Habitat degradation } \\
\text { Altered fire } \\
\text { regimes } \\
\text { History of poor } \\
\text { logging practices }\end{array}$ & $\begin{array}{l}\text { Reduce risk of } \\
\text { catastrophic fire } \\
\text { Restore the link } \\
\text { between livelihoods } \\
\text { and the forest } \\
\text { Protect resources } \\
\text { (mushrooms, basket } \\
\text { material) } \\
\text { Reduce herbicide } \\
\text { use }\end{array}$ & $\begin{array}{l}\text { Community in } \\
\text { transition because } \\
\text { of changing forest } \\
\text { policy, timber } \\
\text { industry restructuring, } \\
\text { and demographic } \\
\text { change } \\
\text { Increasing poverty } \\
\text { Cultural conflict } \\
\text { over land and } \\
\text { resource use } \\
\text { Declining institutional } \\
\text { capacity } \\
\text { Primarily Anglo }\end{array}$ & $\begin{array}{l}\text { Address conflict } \\
\text { Build relationships } \\
\text { among organizations } \\
\text { and agencies } \\
\text { Build contractor } \\
\text { capacity } \\
\text { Support traditional } \\
\text { resource-based } \\
\text { economy } \\
\text { Civic science and } \\
\text { social learning }\end{array}$ \\
\hline
\end{tabular}




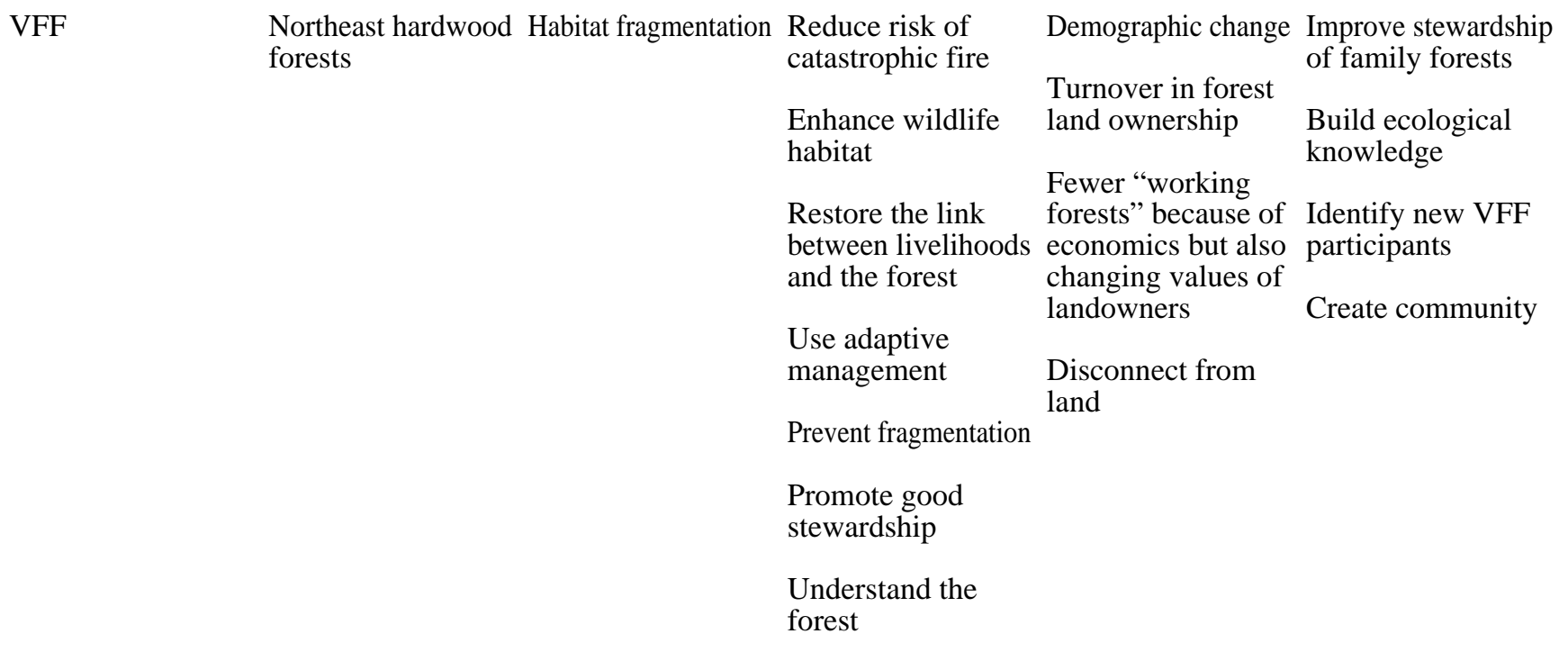

\footnotetext{
AFWH - Alliance of Forest Workers and Harvesters

FSC - Federation of Southern Cooperatives Forest Legacy Program

JBC - Jobs and Biodiversity Coalition

PLP - Public Lands Partnership

WR - Wallowa Resources

WRTC - Watershed Research and Training Center

VFF - Vermont Family Forests
}

grazing permits could provide more frequent observations and insights that could be valuable for managing public lands. For the AFWH, the goal of integrating knowledge was to address conflict among harvesters and influence agency policy about nontimber forest products (NTFP). Because the $\mathrm{CBF}$ groups were part of a learning network of $\mathrm{CBF}$ organizations, they used similar outreach and recruitment methods to include local knowledge holders, targeting people who had experience with the resource. The CBF groups conducted outreach via flyers, newsletters, and radio and newspaper announcements as well as word of mouth. Representatives from environmental organizations concerned with a particular resource as well as federal, state, county, and Native American tribal resource agencies were invited to meetings, field tours, and monitoring committee meetings.
We found that local people, such as NTFP harvesters, ranchers, loggers, Native American tribes, and other long-time resource users as well as other local residents, were involved in some way in all of the 24 projects studied, and that the LEK held by these community members contributed to the project outcome or products (Table 2). In six of the 24 projects, the main responsibility of the local people was collecting field data during assessment or monitoring projects (Table 2). In five of the 24 projects, the primary source of local knowledge for the project was the CBF group's staff members. However, the remaining 13 of the 24 projects involved a combination of volunteer or paid data collection by local residents, significant CBF staff contributions, and the explicit and direct involvement of local people in the planning, assessment, and interpretation of monitoring results (Table 2). These 13 projects exhibited most clearly 
the use of LEK through the participation of a variety of knowledge holders in the community. Three of these projects included documenting LEK as a primary focus of the project (Table 2). Finally, six of the 24 projects specifically sought out participants or representatives from local Native American tribes in an attempt to incorporate traditional ecological knowledge into the project because of their extensive knowledge and long-term history on the land as well as respect for tribal interests in the land being monitored.

\section{Documenting local ecological knowledge}

Three CBF groups conducted formal local or traditional knowledge documentation studies. For example, PLP conducted a "living history" or oral history project, primarily of ranchers' experiences with land management and the local ecosystem in the Uncompaghre Plateau area of Colorado. The FSC conducted a study in their region by interviewing local African-American residents in southern Alabama about useful medicinal and edible plants in their area. They conducted extensive outreach and education for landowners, but said that they always began with owners' existing ecological knowledge about their land. As an FSC staffer explained, "People are familiar with things, they know how to survive and make money doing those things. [We just] have to add a little bit more into that." The NTFP inventory conducted by the WRTC was also a means of formally documenting the LEK of the medicinal plant harvesters in the Trinity Mountains of northern California. Although not all these documentation studies directly changed forest management by the CBF groups or agencies, the studies often brought resource users and residents into local discussions about forest stewardship in ways that other activities, such as scoping meetings, did not.

\section{Involving local people in data collection}

For the six projects involving local people specifically in data collection for monitoring or research, participants contributed their knowledge of the landscape, local fire history, wildlife behavior and habitats, and locations and extent of sensitive or useful plant species (Table 2). For example, the WRTC employed several of the local people who had been trained in their ecosystem management training program to conduct biological surveys for the Bureau of Land Management, the U.S. Forest Service, and other agencies in the region. The participants' local knowledge of the landscape and habitats enhanced their ability to conduct the inventories. These trainees were among the first people in the northern California community to recognize the key role of fire in the ecosystem and the fact that fire's ecological function was missing. As one WRTC staff person described it, "These loggers came back ... and said, 'Oh, my gosh, fire is the driver in this ecosystem, there is too much $\mathrm{s}$ _ $\mathrm{t}$ on the ground, you have to help us figure out how we are going to reduce this vegetation." "The WR has also involved at least five local residents of the Post Mountain neighborhood in collecting forest overstory and understory data before and after stand treatments for their collaborative stewardship project. Similarly, WR hired local contractors to conduct species surveys of lynx, eagle, and grouse as well as monitoring projects. The WR staff felt that local contractors' knowledge of the landscape proved invaluable in conducting these surveys in a cost-effective, efficient manner.

\section{Local ecological knowledge in project design and interpretation of results}

Thirteen projects explicitly incorporated LEK through the participation of a variety of knowledge holders in the community throughout the process of monitoring or research. For example, during the Chopsticks project, WRTC staff-who were all local residents, some of them retired U.S. Forest Service staff and former loggers-not only developed the stand prescriptions that were eventually implemented but also conducted the "before and after" monitoring of the projects that allowed the group to determine the relatively minimal effects their treatment had on the forest topsoil. On a larger scale, WR facilitated a 70 415.3ha (174 000-acre) watershed assessment in which they explicitly appointed people with particular resource experience to subteams, targeting the design and analysis phases of the Upper Joseph Creek Watershed Assessment (UJCWA). The 30 people on the subteams focused on range, forest, and riparian areas, and on roads and cultural resources. The whole project involved more than 70 local people and agency personnel. As one WR staffer explained, "We tried to get at least one person with intimate knowledge of wherever we were. For example ... another gentleman has run cows out there for a long time, and he was part of the range group [for the UJCWA]. So while not ... a range professional, we sought him out for his knowledge of the ground." The WR staff characterized this as 
Table 2. Overview of projects, participants, and use of local ecological knowledge and conventional science in 24 projects of the seven community-based forestry $(\mathrm{CBF})$ groups studied.

\begin{tabular}{l}
\hline \hline $\begin{array}{l}\text { CBF g- Project } \\
\text { roup }\end{array}$ \\
\hline
\end{tabular}

AFWH Mushroom monitoring Local mushroom pickers

Weed removal and

Local NTFP harvesters

Cave Junction forest Local forest workers worker training in Scientist consultant field methods

CBF staff

FSC Oral history project Community

University researcher

Goat agroforestry Local residents project monitoring

Agencies

Scientist consultants

CBF staff

Mill Site \#2 fuels treatment project

Community youth

Agencies

Scientist consultants

CBF staff

PLP Uncompaghre Plateau Local residents and Project watershed loggers assessment and monitoring

\section{U.S. Forest Service}

Environmental organizations

CBF staff

Scientist consultants
Harvester knowledge of location of species and impact of harvest

Collected photo point data and compiled mushroom identification notebook $^{\dagger}$

Forest workers' knowledge of location and extent of weeds, working to locate and pull weeds in nonherbicide treatments $^{\dagger, \S}$

Forest workers' knowledge of the landscape

Local residents' knowledge of land-use history, species ${ }^{\dagger, \mathbb{I}}$

Local resident's knowledge of animal husbandry ${ }^{\dagger}$

CBF staff knowledge of stand dynamics and effects of fire ${ }^{\#}$

Scientifically trained CBF staff trained harvesters to collect biophysical data, photo points

$\mathrm{CBF}$ is part of a bioregional working group on noxious weeds

Networking and sharing removal methods

Scientifically trained CBF staff trained members to collect biophysical data

Scientist consultant trained forest workers in field data collection methods to increase job skills

NA

CBF group provided local people with information and training about agroforestry and forest management plans $^{\ddagger}$

Agencies contributed to and approved stand prescriptions

Scientist consultant trained locals and directed monitoring project using standardized protocols ${ }^{\ddagger}, \uparrow$

CBF staff knowledge of stand dynamics and effects of fire ${ }^{\#}$

U.S. Forest Service contributed to and approved stand prescriptions Scientist consultant trained locals and directed monitoring project using standardized protocols

U.S. Forest Service and scientists from environmental organizations contributed to management activities knowledge of ecosystem functioning and effects of fire

Scientist consultants designed Participated in planning meetings and analysis of data ${ }^{\dagger, \S}$ monitoring and assessment ${ }^{\dagger \dagger, t+}$ 


$\begin{array}{lll}\begin{array}{l}\text { Burn Canyon } \\ \text { project and } \\ \text { monitoring }\end{array} & \begin{array}{l}\text { Local residents and } \\ \text { loggers }\end{array} & \begin{array}{l}\text { Local residents' and loggers' } \\ \text { knowledge of ecosystem status and } \\ \text { process and effects of fire }\end{array} \\ \begin{array}{l}\text { U.S. Forest Service } \\ \text { environmentalist }\end{array} & \begin{array}{l}\text { Participated in planning meetings and } \\ \text { analysis of data }\end{array} \\ & \text { CBF staff } & \end{array}$

CBF staff

University scientists
Many federal and state agencies

Local tribes

University scientist

Interest group

CBF staff

Aspen and landbird habitat monitoring

Haypen fuels thinning project

$\begin{array}{ll} & \text { Agencies } \\ & \text { Interest groups } \\ & \text { CBF staff } \\ \begin{array}{l}\text { Buck stewardship } \\ \text { project }\end{array} & \text { CBF staff } \\ & \text { Agencies } \\ & \text { Interest groups } \\ & \text { Scientist consultant } \\ \begin{array}{l}\text { Wallowa Lake } \\ \text { wildland-urban } \\ \text { interface project }\end{array} & \text { Local residents } \\ & \text { Agency } \\ & \text { CBF staff } \\ \text { Weed monitoring } & \text { CBF staff } \\ & \text { Agencies }\end{array}$

Environmental organizations

Federal agency

Scientist consultant

CBF staff

Local residents

Agencies

Local residents' knowledge of impacts of fuels thinning project and vegetation $^{\#}$

Local residents' and ranchers' knowledge of land use history and effects of fire ${ }^{\dagger, \S, \mathbb{I}}$

Ranchers' knowledge of grasslands and range management

Loggers' knowledge of forest and forest management

Tribes' traditional knowledge of watershed functioning and management $t^{\dagger, \S}$

CBF staff knowledge of the habitats and threats

Local field technicians' knowledge of the landscape and habitats

$$
\text { vetation }
$$

CBF staff knowledge ${ }^{\#}$

Local residents' knowledge of landscape and effects of mixed land use $^{\#}$

Local residents' knowledge of location and extent of weeds

CBF staff knowledge ${ }^{\dagger}$
U.S. Forest Service and university scientists helped design salvage logging treatments and conducted monitoring project $^{\dagger \dagger, t *}$

NA
Agency personnel involved in each monitoring subteam

University scientist involved in design and analysis of data $\uparrow+,+\uparrow$
Scientist consultant and agency personnel contributed to the design and $\underset{i \dagger}{\text { analysis of data for project monitoring }} \stackrel{t}{\text {, }}$

Agency personnel involved in multiparty monitoring project ${ }^{+\dagger}$
Scientist consultant contributed to data collection and analysis of monitoring project

Agencies provided scientific oversight for data collected and applied recommendations to management ${ }^{\dagger \dagger, \S \S}$

Agency personnel involved in multiparty monitoring project ${ }^{\ddagger \neq}, \S \S$

Local residents 
Lynx survey

Eagle survey
Local contractors

Agency

CBF staff

Local contractors

Agency

CBF staff

High school students

Agency

CBF staff
Local contractors' knowledge of lynx habitat and presence/absence

CBF staff scientist trained local contractors in data collection

Agency provided oversight

Scientist consultant hired for quality control of data collection by

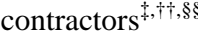

Local contractors' knowledge of eagle habitat and presence/absence

CBF staff scientist trained local contractors in data collection

Agency provided oversight

CBF staff scientist trained local

Local contractors' knowledge of grouse habitat and presence/absencel contractors in data collection

Agency provided oversight ${ }^{\ddagger} \S \S$

Local trainees' knowledge of landscape features and habitat

Agencies

Scientist consultants

CBF staff

Chopsticks fuels treatment project and monitoring

Local trainees

University researcher

CBF staff

NTFP assessment and harvest inventory and research

Local NTFP harvesters

University researcher

CBF staff

Post Mountain stewardship collaborative project and monitoring

Localresidents

Agencies

Interest groups

Consulting forester

CBF staff

VFF Development of Forest Stewardship Council Criteria and Environmental groups Indicators for Forest certification

Agencies

CBF staff

CBF staff knowledge of forest management and fuel treatments

Local trainees knowledge of landscape features and habitat

Harvesters' knowledge of medicinal plant location and the extent and impacts of harvest contributed to the design and collection of data for inventory and research projects ${ }^{\dagger, \S, \mathbb{I}}$

Local residents' knowledge of their forest and effects of fire and fuels treatment

Multiparty planning and implementation of forest stand treatments

Local residents trained to collect data for monitoring project ${ }^{\dagger}$

Local landowners' knowledge of forest and forest management, habitat

Involved in development of forest certification criteria for the region
CBF staff scientists trained local people in data collection and ecosystem management

Agency provided scientific oversight ${ }^{\ddagger}, \S \S$

Scientist consultant hired to train local people and to design, collect, and analyze monitoring data

CBF staff scientist hired to train local people and to design, collect, and analyze research data

Agency personnel involved in multiparty planning and implementation of forest stand treatments, consulting forester and CBF staff trained local people and designed and collected monitoring data ${ }^{i,+\dagger},+\sharp$
Scientists from agencies and environmental groups involved in the development of forest certification criteria for the region 


\author{
AFWH - Alliance of Forest Workers and Harvesters \\ FSC - Federation of Southern Cooperatives Forest Legacy Program \\ JBC - Jobs and Biodiversity Coalition \\ PLP - Public Lands Partnership \\ WR - Wallowa Resources \\ WRTC - Watershed Research and Training Center \\ VFF - Vermont Family Forests \\ NTFP - Nontimber forest product(s)
}

One of 13 projects in which the use of LEK clearly contributed to the final product.

${ }^{\ddagger}$ One of 14 projects in which conventional scientists trained local people in standardized data collection methods.

${ }^{\S}$ One of six projects in which the CBF group sought the involvement of local tribes or that incorporate traditional ecological knowledge.

One of six projects in which the main responsibility of the local people was collecting field data.

"One of three projects in which the documentation of LEK was a primary focus.

\#One of five projects in which the local people involved were mainly staff members of the CBF organization.

One of 11 projects in which scientists were hired to design, conduct, and analyze a monitoring project.

$\$$ One of eight projects in which scientists participated in multiparty monitoring teams or monitoring subcommittees.

${ }^{\S}$ One of six projects that involved conventional science primarily in the form of oversight by a government agency that determined the treatment or monitoring methods used.

a key component of the project, because the local ranchers and other resource users provided an important ground-truthing function when it was time to interpret the ecological data.

Another example of the explicit use of LEK is the PLP's Uncompaghre Plateau and Burn Canyon projects. The PLP brought together stakeholders from within and outside the community, as well as federal agency personnel, to discuss the ecosystem health and management of the two areas. The ecosystem "mosaic" model used to guide the Uncompaghre Plateau forest management project was largely science driven, but it was developed in part through a series of workshops and discussions that included community members and PLP staff. The PLP also emphasized the participation of local people in the interpretation of monitoring data in the Burn Canyon project, which focused on the effects of a large stand-replacing fire. Several participants reported how experiential and observational knowledge were used to interpret the monitoring results or to enrich the group's overall understanding of the area. Ranchers grazing cattle on public lands observed the presence of an exotic species, increased water runoff and sediment after the fire, decreased mushroom abundance in a grazing exclosure, and the return of wildlife to the salvage logging areas.
An important focus for two of the CBF groups was the NTFP harvesters' LEK. The AFWH provided mini-grants and technical support to an active group of primarily Southeast Asian mushroom harvesters in Oregon who conducted an informal assessment of productive mushroom patches in the national forest. In another forest, harvesters created maps of commercial mushroom areas and, after extensive conversations with U.S. Forest Service personnel, a slated timber harvest was moved to protect the highly productive areas. Similarly, the WRTC sponsored an inventory of NTFP in the TrinityShasta National Forest and explicitly involved local medicinal plant harvesters. The harvesters collaborated with the WRTC staff ecologist to study the relative abundance of all the useful species in the region, in several cases finding that the range of a species extended beyond the range documented by the U.S. Forest Service.

\section{Involving Native American tribes in community- based forestry projects}

An important part of increasing public involvement for six projects of the CBF groups was actively seeking the involvement of local tribes or otherwise incorporating indigenous knowledge into their monitoring and stewardship work (Table 2). Although none of the projects were on tribal lands, 
in most cases those on public lands involved areas historically used by neighboring tribes. Hence, even though CBF groups often had one or more tribal representatives on their boards, additional tribal members were often sought or invited to participate in particular projects appropriate to the resources being studied. The AFWH, PLP, WRTC, and WR often tried to facilitate involvement by inviting tribal representatives to scoping meetings related to proposed management activities in the national forest, or by holding more informal discussions with tribal resource users who might have an interest in the CBF group's activities. For example, the PLP invited the Northern Utes to participate in a Uncompaghre Plateau symposium they sponsored on the piñon-juniper and sagebrush system. As a U. S. Forest Service staff member pointed out, "The whole idea of valuing traditional ecological knowledge has improved currency over where it was previously ... [I] am frankly very pleased that PLP is making that effort and engaging [the Utes] because it is a question of capacity and I do not have a lot of extensive contacts." The WR also actively invited participation from the Nez Perce in the UJCWA, and several representatives from the tribe participated in the resource assessment subteams. The WR also has Nez Perce Tribal members on its board. The AFWH collaborated consistently with California Indian basket weavers and native plant gatherers in their weed removal and monitoring project (Table 2). In this project, forest workers, commercial NTFP harvesters, and Native American plant gatherers all had the common goal of promoting nonherbicide weed removal methods that slow the spread of noxious weeds but do not endanger the health of the people who work in and use materials from the forest.

\section{Using conventional science}

Of the 24 stewardship and monitoring projects conducted by the CFB groups, 22 involved scientists, either as consultants or university researchers, or resource professionals from federal, state, or local government agencies who were professionally trained to use conventional science and scientific methods in their work, and these projects used conventional science in some way. In 14 projects, conventional scientists trained local people in standardized data collection methods; in 11 projects, scientists designed, conducted, and/or analyzed the monitoring project; in eight projects, scientists participated in multiparty monitoring subcommittees or teams; and in six projects government agencies determined the treatment or monitoring methods used based on conventional science (Table 2). We found no evidence of cooptation of local knowledge or knowledge holders by scientists in any of the projects.

\section{Training local people in conventional science tools}

In 14 of the projects, local residents received training in formal data collection methods and watershed assessment techniques to complete projects for agencies and/or in-house projects (Table 2). For example, the WRTC employed several local people to collect the data for monitoring the Chopsticks fuels treatment project and trained at least five local residents of the Post Mountain neighborhood to collect forest overstory and understory data. The AFWH sponsored training workshops led by a scientifically trained CBF board member for forest workers who typically plant trees and prune and thin stands. These ecological fielddata collection skills were expected to increase workers' options for employment with natural resources agencies.

In the case of the FSC, conventional science was used as a way to gain access to technical resources for landowners to help them manage their land better. As one FSC staff put it, "Everyone does that [assessing and monitoring resources] in their head. Maybe the next step is to write it down, pay more attention to it. What we always talk to people about is: Do you have a management plan? You might have it in your head, but to get help from NRCS [Natural Resource Conservation Service], if you don't have a plan, you won't get help. If you show a landowner a management plan they get so excited." Through one-on-one outreach, peer-topeer learning networks, and partnerships with state commissions and universities, the FSC connected landowners to more formal ways of documenting their land ownership and benefiting from management plans.

\section{Hiring conventional scientists}

For most of the 13 projects in which the CBF group hired outside scientists, the primary role of the conventional scientist was to design a monitoring or research project using rigorous sampling design and methodology. This would allow the CBF group to learn about the impacts of their management activities and to potentially communicate these 
results to their partner organizations and critics (Table 2). For example, the WRTC hired a scientist for several years to design the monitoring and research protocols, train the local community members, and conduct and analyze the projects for both the Chopsticks fuels treatment project and the NTFP inventory and research projects. The JBC partnered with a scientist through the Collaborative Forest Restoration Program of the U.S. Forest Service to train local students and design and conduct the monitoring project for Mill Site \#1, and also hired a scientist as a monitoring coordinator to repeat that process with Mill Site \#2. In all of these cases, the scientist was hired by the CBF group to conduct the monitoring project and was always partnered with either staff from the CBF group or local community members.

The CBF groups also used partnerships with conventional scientists to navigate the obstacles inherent in offering data collected by local people to federal land-management agencies. The WR faced significant skepticism from the federal agencies for which they coordinated several threatened and endangered species surveys to be conducted by local contractors on the grounds that this would bias the results, so they hired an outside professional ecologist as a third-party auditor. A staff member explained, "We trained three or four people from the community up at the Forest Service. But because they were residents and because everybody was skeptical about the results, we then had a wildlife biologist from the University of Idaho do quality control. And he came back with just a glowing report about what an exceptional job everybody had done."

In some cases, conventional science gave the CBF groups the tools to confirm their assumptions about the effects of their forest treatments. For example, several members of the JBC hoped that monitoring would measure what they already knew to be the best approach to thinning, which they could then demonstrate to the Forest Service. One JBC member commented, "The monitoring is irrelevant to some extent. Well, it's relevant to measure what we've done because right now it's basically an art. This is what we think should be done based on our experience." Similarly, one WRTC staff person suggested that years of observations on the ground would likely be validated by the findings of conventional science, noting that, "It's an opportunity to test those theories around what you already think you've learned and experienced from being in fires and watching trees. When you've seen the effects of the fires, 20 years later the build-up of fuels, I think you have theories, and those things just give you an idea and validate your assumptions."

\section{Evidence of knowledge integration by community-based forestry groups}

The CBF groups conducted 20 projects that involved both local people, e.g., residents, resource users, landowners, and youth, and those trained in conventional science, including public resource agency personnel, university scientists, and consulting foresters. We found evidence that participants or partners of all seven $\mathrm{CBF}$ groups integrated local and conventional science based on one or both of our indicators: participants' statements about the value and usefulness of different knowledge types and documented integration in written reports or other project documents. Most importantly, in each project, conventionally trained scientists and local people both described learning from each other, and learning about the experiences that gave rise to their knowledge, whether it was the result of living in the same forest for 50 years or studying journal articles related to fire frequency in the region.

\section{Local people's attitudes toward conventional science}

Several participants in both projects conducted by the PLP described ways in which the CBF projects increased local people's understanding of the scientific process and of the ecosystem of which they were a part. During the Uncompaghre Plateau project, participants reported that research conducted by a Colorado University Ph.D. student shifted their understanding of piñon-juniper fire dynamics on the plateau. A Bureau of Land Management ecologist made this observation about the changing opinions of the participants in response to the student's findings: "What she found didn't jive with everybody's belief of what was going on, but we watched as people slowly came around. And so there was a paradigm shift that came about as a result of that research that [the UP Project] funded, and people who were kind of unwilling eventually came around since it was all in forum and you know, it was discussion. It wasn't like you received the findings in a paper and read it in your office and kind of dismissed them." One PLP participant and 
observer felt that PLP community members learned much about science from participating in project field trips as well as discussions, leading to a better appreciation of the scientific basis for agency decisions and of the complexity of ecosystems generally.

The WR intentionally addressed the biases against conventional science that many of their community members had expressed when they first began working on ecosystem management and restoration projects. One long-time local resident and WR staff member explained how the local negative attitudes toward science were transformed by the fact that WR embraced science as a part of its economic development work and had become a foundation of their approach to CFB: "It really led to a new way of doing natural resource management. A way of engaging the local community, of connecting science. To a lot of people, science had been our enemy, science and research had been our enemy because it had been treated as a god. And [it] lacked that connection with peoples' local connection with the ground. Blending science has led to the basic values of Wallowa Resources."

Another long-time local resident and WR staff person who coordinated the organization's invasive species program described his perspective on their collaboration with a local U.S. Forest Service research scientist. "That's a nice partnership. A lot of research is going into treatment methods [for invasives] ... I helped design and implement the chemical end of her research. In her research, there are replicated plots, all the bells and whistles she needs to say something." Because WR emphasized the positive role that science can play in CBF, the WR staff person saw this research as a mutually beneficial partnership with a scientist, rather than an extraneous addition to his workload.

\section{Conventional scientists' attitudes toward local ecological knowledge}

Many of the conventional scientists involved with the CBF groups interviewed expressed an increased appreciation for the value of local knowledge in implementing and monitoring new land-management practices as well as for learning about the landscape through monitoring and assessment. Scientists working with the WRTC, the AFWH, the JBC, and WR all commented that the knowledge and experience of local people helped them create more "realistic" monitoring or research protocols that increased the applicability of their research to the projects on the ground. For example, The Nature Conservancy (TNC) scientist working with WR on its invasive species projects explained how the local WR staff person's methods of tracking weed abundance were more pragmatic and useful than what his conventional science protocols called for: "You've got 1000 acres [405 ha] to ... measure ... and track through time. No one's done it in a way that's meaningful at that scale. You would need a million transects. [When the WR staff person says] that this 50-acre [20-ha] site took two gallons [7.6 L] of chemical, next year one gallon [3.8 L], the next year $1 / 2$... that's as good as any. Otherwise, it's just impossible." The WR staff's documented quantities of herbicide required for an area gave this TNC scientist a sufficient estimate of the weed population.

Similarly, although one scientist working with the WTRC had designed thorough and rigorous protocols for monitoring the impacts of the Chopsticks project forest thinning treatment, she later reflected on whether it had been more work and data collection than was necessary. When asked if she'd have any recommendations for other $\mathrm{CBF}$ groups for setting up a monitoring project based on her experiences, the scientist replied, "Keep it simple. Keep it really simple. Photo points. Once a year revisit. Whatever makes sense so you can actually monitor what you're monitoring, but don't try to have it be [too] scientifically credible." In the same study, the conventional scientist described how she learned about the delicate balance between scientific rigor and local applicability by working with local people, and in the end valued the experience of the local people: "I think you'd still be much better off doing the bottom up, working with the community approach."

Several professionals working with the CBF groups also described their sense that local resource users contributed additional knowledge or experience to the project. For example, a scientist hired by the JBC to coordinate its monitoring program said, "I know when I've gone out into the forest with [the local JBC staff], they see things that I don't see, you know what I mean? They can just see stuff that's not obvious to me. So I think they assess it when they are out there, and they might not even always say anything about it, but to them it's obvious." Similarly, a partner working with the AFWH commented during a discussion about the mushroom harvesters, "You build the ecosystem 
from the bottom up. The balance and health rests on the backs of the people at the bottom, and they need to be given credit and honored for that." In many of these projects, the scientists described a change in their attitudes about local knowledge holders after working with individuals over an extended period of time.

\section{Products that include both local knowledge and conventional science}

Five of the $\mathrm{CBF}$ groups produced written products such as reports and other documents that integrated LEK and conventional science (Table 3). Three of the products were directly applied to forest management recommendations or decisions: WR's UJCWA document, the VFF's contribution to the Forest Stewardship Council Criteria and Indicators for Forest Certification, and the PLP's mosaic model (Table 3). Although these documents were written to be used by local land managers such as ranchers and private forest landowners, they were also intended to satisfy the needs of agencies and outside scientists, so the language is professional and scientific. In contrast, the WRTC's NTFP guidelines and the AFWH's mushroom photo notebook were produced primarily by and for local people and use everyday language and graphics or photos for wider accessibility, but are also used by regional agency professionals. Although these products vary in their formality, general application, and distribution to other parties, they were all produced jointly by local knowledge holders and scientists in one integrated document, and they were all used by both local people and scientists to further their understanding of the ecosystem or improve forest management.

\section{DISCUSSION}

The ways in which CBF groups have sought out and incorporated LEK into their stewardship activities illuminates both the value that LEK has for the participants in these organizations and the challenges that $\mathrm{CBF}$ groups face when they try to include LEK in forest management and science. Most notably, our findings illustrate the way in which CBF groups can gain access to power and influence forest management and monitoring through the integration of LEK and science. The effects of this improved access on land management, as well as the many other outcomes of the collaborative monitoring projects, are discussed thoroughly in Fernandez-Gimenez et al. (2008). For many CBF groups, integrating LEK with conventional science is not merely an intellectual exercise, but an important vehicle to gain entry into the realm of science that has the power to influence management and policy. Castillo et al. (2005) discuss how resource users can "use" ecology as a tool just as they use their own experiential knowledge. In our research, CBF groups used conventional science as a tool more often than we had expected. In many cases, CBF groups sought to empower participants with conventional science rather than seeking equal footing for local knowledge. For several groups, participating in and sometimes controlling ecological monitoring of a resource is not only about learning about the land, but also about getting a voice in the management process. By hiring their own scientists, training local people in scientific methods, and exposing local people to conventional science through field tours and monitoring committees, CBF groups helped the locals learn the language, methodological framework, and concepts of conventional science. This helped CBF staff and participants understand and communicate with scientists and agency managers in new ways.

The CBF groups who particularly focus on underserved groups used conventional science to make small but significant strides toward the democratization of science. The photo identification binder produced by the primarily Southeast Asian mushroom harvesters during the mushroom monitoring project sponsored by the AFWH documented mushroom species in the national forest and potentially paved the way for future collaborations between harvesters and the U.S. Forest Service. Similarly, community members who worked with the FSC pointed out that gaining access to conventional science knowledge allowed them to work with foresters on a more equal footing and gain access to resources from the state agency, which had previously been unconcerned with small landowners. Some of the innovative and successful participating landowners independently sought training and written information that they adapted to local contexts and demonstrated for other FSC members. In both cases, CBF groups reported that community members were using more sustainable management practices as a result of their participation. These findings are consistent with other studies that conclude that local participation in conventional science projects improves 
Table 3. Products of community-based forestry groups that included both local ecological knowledge and conventional science.

\begin{tabular}{|c|c|c|c|}
\hline Product & $\mathrm{CBF}$ group and project & How was it produced? & What is it used for? \\
\hline $\begin{array}{l}\text { Assessment report on } \\
\text { condition of resources }\end{array}$ & $\begin{array}{l}\text { WR Upper Joseph } \\
\text { Creek watershed } \\
\text { assessment }\end{array}$ & $\begin{array}{l}\text { Resource subteams included at } \\
\text { least one local resource user and a } \\
\text { USFS scientist }\end{array}$ & $\begin{array}{l}\text { USFS personnel describe the } \\
\text { assessment as "useful to-do" list } \\
\text { for projects in the national } \\
\text { forest"" }\end{array}$ \\
\hline $\begin{array}{l}\text { USFS General Technical } \\
\text { Report on Non-Timber } \\
\text { Forest Products (Everett } \\
\text { 1997) }\end{array}$ & $\begin{array}{l}\text { WRTC NTFP } \\
\text { assessment and harvest } \\
\text { inventory and research }\end{array}$ & $\begin{array}{l}\text { Produced jointly by an ecologist } \\
\text { and local medicinal plant } \\
\text { harvesters conducting the } \\
\text { inventory, including Native } \\
\text { American harvesters }\end{array}$ & $\begin{array}{l}\text { Disseminated by the USFS free } \\
\text { to anyone who requests it }\end{array}$ \\
\hline $\begin{array}{l}\text { Illinois Valley Mushroom } \\
\text { Monitoring Project Photo } \\
\text { Notebook }\end{array}$ & $\begin{array}{l}\text { AFWH mushroom } \\
\text { monitoring }\end{array}$ & $\begin{array}{l}\text { Harvesters compiled a notebook } \\
\text { of local mushrooms to educate } \\
\text { other harvesters and USFS } \\
\text { personnel after receiving training } \\
\text { on field data collection methods }\end{array}$ & $\begin{array}{l}\text { Has served as a vehicle for } \\
\text { communication between USFS } \\
\text { managers and harvesters }\end{array}$ \\
\hline $\begin{array}{l}\text { Forest Stewardship Council } \\
\text { (FSC) Criteria and } \\
\text { Indicators for Forest } \\
\text { Certification }\end{array}$ & $\begin{array}{l}\text { VFF Development of } \\
\text { forest stewardship } \\
\text { council criteria and } \\
\text { indicators for forest } \\
\text { certification }\end{array}$ & $\begin{array}{l}\text { Forest landowner members and } \\
\text { scientists from VFF partner } \\
\text { organizations provided input into } \\
\text { the criteria. }\end{array}$ & $\begin{array}{l}\text { Criteria used for third-party } \\
\text { certification of timber producers } \\
\text { in the northeastern USA }\end{array}$ \\
\hline Mosaic Model & $\begin{array}{l}\text { PLP Uncompaghre } \\
\text { Plateau (UP) }\end{array}$ & $\begin{array}{l}\text { Workshops involving local people } \\
\text { and scientists examined landscape } \\
\text { assessment and discussed } \\
\text { historical range of variation for } \\
\text { each plant community on the } \\
\text { plateau. }\end{array}$ & $\begin{array}{l}\text { Model of the ecosystem as } \\
\text { shifting mosaic of vegetation } \\
\text { types used in all UP project } \\
\text { forest management } \\
\text { recommendations }\end{array}$ \\
\hline
\end{tabular}

AFWH - Alliance of Forest Workers and Harvesters

FSC - Federation of Southern Cooperatives Forest Legacy Program

JBC - Jobs and Biodiversity Coalition

PLP - Public Lands Partnership

WR - Wallowa Resources

WRTC - Watershed Research and Training Center

VFF - Vermont Family Forests

USFS - U.S. Forest Service 
commitment, trust, and the adoption of new management practices (Calheiros et al. 2000, Ticktin and Johns 2002, Castillo et al. 2005).

Despite these successes, two primary obstacles remain for $\mathrm{CBF}$ groups trying to integrate local knowledge and conventional science into their stewardship activities: reaching and including in ongoing interactions with scientists both Native American tribes and traditionally under-represented groups such as immigrant harvesters, some of whom are undocumented, and very poor AfricanAmerican landowners. Wilson et al. (2006) assert that, for the LEK of resource users to truly make an effective contribution to management, it must be part of "comprehensive studies involving ongoing interactions between resource users, scientists, and other stakeholders." Our findings show that these groups have been included in many CBF projects, but their participation has either been inconsistent, or the ways in which they were included do not involve interactions with scientists in any lasting way. This obstacle stems from both the reluctance of community members to participate and the apparent reluctance of agency scientists to use data collected in less formal ways. Private landowners such as the FSC and VFF may also suspect that scientific data are not always used to further landowners' goals but rather to evaluate whether they complied with a regulation. For groups such as the FSC and AFWH, which spread across a large region and/or are geographically isolated and have limited technical staff and resources, skepticism remains about the benefits of science and scientific monitoring. Agency scientists, who are often responsible for providing scientific evidence to justify management actions, are sometimes reluctant to rely on data collected by other than approved methods, as was the case with the AFWH. Community members in these FSC and AFWH cases worked without ongoing interaction with scientists.

Similarly, although Native American tribes have participated in various CBF projects and events as described in our results, their involvement in monitoring and management projects with CBF groups has not been extensive and their knowledge has not yet been consistently incorporated. Attempting to include tribes in the work of $\mathrm{CBF}$ groups raises particular challenges at a number of levels: the overextension of the tribe in trying to work on many issues throughout the region; differences in priorities, communication, and decision making in working between multiple government bureaucracies; and the fact that collaboration cannot and should not replace government-to-government consultation with tribes. Native American tribes often conduct ongoing negotiations with the U.S. government about ownership and use of land and resources on public lands, so that a $\mathrm{CBF}$ group that initiates a monitoring project in a national forest faces particular challenges in its collaborative efforts.

An additional obstacle may have been the relationships of power already in place for the traditionally under-represented local people and Native American tribes who were asked to be involved in monitoring by $\mathrm{CBF}$ groups. For some local people, formal structures such as meetings in offices and symposia with presentations may have reinforced the power inequities and made participation more difficult. This is consistent with Nadasdy's (1999) critique that the project of integrating traditional ecological knowledge and science can ignore the contexts and ways in which knowledge is generated, bolstering the dominant system in an effort to make the integrated information "compatible with the already existing institutions and processes of scientific resource management." In contrast, although many Native American tribal representatives are very familiar with these formal institutions, some perceive that participating in collaborative processes might threaten their right to negotiate government to government, or at least others' perceptions of their status as a sovereign nation. Although some CBF groups were able to challenge these existing power imbalances with monitoring projects that integrated the knowledge of under-represented groups such as AFWH mushroom harvesters and the WRTC nontimber forest products inventory, they need to continue to navigate the most effective and ethical processes for working with Native American tribes. It is also important to note that all the CBF groups were constrained by certain institutional arrangements that limit power redistribution, that is, their work on federal lands meant that ultimately decision making was in the hands of federal land managers.

The CBF projects that successfully integrated LEK and conventional science involved ongoing interactions, such as monitoring committees, research projects, and stewardship projects, with consistent participation by individuals who formed long-term relationships of mutual respect and interest. Many of the empirical studies of knowledge 
integration, some of which involved indigenous resource management, report a similar strategy (Gilchrist et al. 2005, Fernandez-Gimenez et al. 2006, Wilson et al. 2006). Although on the surface these interactions might have posed the risk of allowing scientists to co-opt LEK and LEK holders, the $\mathrm{CBF}$ groups facilitated and controlled the projects and information generated and thereby prevented co-optation. Although this ongoing interaction may be more challenging to accomplish with traditionally under-represented groups and some Native American tribes because of histories of mistrust, this strategy could be applied more broadly by CBF groups and other community-based science organizations. In addition, an important outcome of these interactions was the discussions between local people and conventional scientists about bias, rigor, and uncertainty, which acknowledged that no one method of knowledge creation is infallible. In the case of many of the CBF groups, their commitment to adaptive management means that uncertainty is openly identified, discussed, and debated among the participants, including holders of different types of knowledge.

\section{CONCLUSIONS}

The seven CBF groups studied were part of a demonstration program intended to explore and test new ways of integrating the economic and social health of communities and the ecological health of forests. The fact that all of these groups chose to incorporate LEK and conventional science in a variety of creative ways indicates that knowledge integration is an important strategy that other groups seeking that balance could also pursue. Our findings also indicate that an interdependent science can exist in the context of forest management in the United States and that community members, conventional scientists, and local scientists can collaborate to jointly produce new information about ecological systems and natural resource management. Although structural inequalities still exist in some cases as mentioned above, all the projects had significant aspects of successful knowledge integration and, in many cases, power sharing between scientists and local communities. This contrasts with studies in which knowledge integration and power sharing were difficult or unsuccessful (Kofinas 2005, Nadasdy 2003). Rather than scientists and managers sprinkling local knowledge into their work as they saw fit, we found numerous cases in which scientists worked in partnership with local people to conduct assessments, monitoring, and research. Rather than waiting for the conventional science to be handed down from agencies or universities, $\mathrm{CBF}$ groups hired scientists, trained local people, and in other ways harnessed conventional science for their own use. The implications for the management of natural resources lie in the broader understanding of the relative uncertainties and potential limitations of conventional science and LEK. Just as conventional scientists increasingly learn the value of sitespecific LEK, local people become more insightful consumers of science.

This study illustrated the potential for CBF groups to play a key role in connecting scientists and local people for natural resource management, enhancing local people's understanding and use of conventional science, and increasing the role of local knowledge in monitoring and research. However, we do not claim that all CBF groups do this. We also acknowledge that our results represent a small sample of CBF groups and projects in the USA. Further study is needed to determine the particular strategies that CBF groups use to integrate LEK and conventional science and assess how extensively the products of knowledge integration are applied outside the domain of the CBF groups. Despite the possible limitations of our sample, our findings show that effectively integrating diverse knowledge sources for forest research and management, rather than co-opting local knowledge or consulting with locals in a token way, can redistribute the power of conventional science into the hands of local people and underserved communities who are typically excluded from the production of science that informs management. This illustrates that interdependent science is about equitable partnerships between people as much as it is about producing better accounts of the world.

Responses to this article can be read online at: http://www.ecologyandsociety.org/voll3/iss2/art37/responses/

\section{Acknowledgments:}

We would like to thank the staff and partners of the community-based organizations who worked with us to develop and implement this study, the Ford Foundation for funding this research, the Aspen Institute, and the Ford CBF Research Team. We 
would also like to thank the three anonymous reviewers who gave us helpful feedback and improved the resulting manuscript.

\section{LITERATURE CITED}

Baker, M., and J. Kusel. 2003. Community forestry in the United States: past practice, crafting the future. Island Press, Washington, D.C., USA.

Ballard, H. L., and L. Fortmann. 2006. Collaborating experts: integrating civil and conventional science to inform management of salal (Gaultheria shallon). Pages 164-180 in K. S. Hanna and D. S. Slocombe, editors. Fostering integration: concepts and practice in resource and environmental management. Oxford University Press, Oxford, UK.

Becker, C. D., and E. Ostrom. 1995. Human ecology and resource sustainability: the importance of institutional diversity. Annual Review of Ecology and Systematics 26:113-133.

Berkes, F. 1999. Sacred ecology; traditional ecological knowledge and resource management. Taylor and Francis, Philadelphia, Pennsylvania, USA.

Berkes, F., J. Colding, and C. Folke. 2000. Rediscovery of traditional ecological knowledge as adaptive management. Ecological Applications 10 (5):1251-1262.

Berkes, F., and C. Folke, editors. 1998. Linking social and ecological systems: management practices and social mechanisms for building resilience. Cambridge University Press, Cambridge, UK.

Borchers, J., and J. Kusel. 2003. Toward a civic science for community forestry. Pages 147-163 in M. Baker and J. Kusel, editors. Community forestry in the United States: past practice, crafting the future. Island Press, Washington, D.C., USA.

Brook, R. K., and S. M. McLachlan. 2005. On using expert-based science to "test" local ecological knowledge. Ecology and Society 10(2): r3. [online] URL: http://www.ecologyandsociety.org/vol10/iss $2 /$ resp3/.
Calheiros, D. F., A. F. Seidl, and C. J. A. Ferreira. 2000. Participatory research methods in environmental science: local and scientific knowledge of a limnological phenomenon in the Pantanal wetland of Brazil. Journal of Applied Ecology 37(4):684696.

Carr, A. J. L. 2004. Why do we all need community science? Society and Natural Resources 17:841849.

Castillo, A., A. Torres, A. Velazquez, and G. Bocco. 2005. The use of ecological science by rural producers: a case study in Mexico. Ecological Applications 15(2):745-756.

Chalmers, N., and C. Fabricius. 2007. Expert and generalist local knowledge about land-cover change on South Africa's Wild Coast: Can local ecological knowledge add value to science? Ecology and Society 12 (1): 10. [online] URL: http://www.ecolo gyandsociety.org/vol12/iss1/art10/.

Colding, J., and C. Folke 2001. Social taboos: "invisible" systems of local resource management and biological conservation. Ecological Applications 11:584-600.

Davis, A., and J. R. Wagner. 2003. Who knows? On the importance of identifying "experts" when researching local ecological knowledge. Human Ecology 31(3):463-489.

Ericksen, P., and E. Woodley. 2005. Using multiple knowledge systems: benefits and challenges. Pages 85-117 in D. Capistrano, C. Samper., M. J. Lee, and C. Raudsepp-Hearne, editors. Ecosystems and human well-being: multiscale assessments. Island Press, Washington, D.C., USA.

Everett, Y. 1997. A guide to selected non-timber forest products of the Hayfork Adaptive Management Area, Shasta-Trinity and Six Rivers National Forests, California. U.S. Forest Service General Technical Report GTR-PNW-162.

Fernandez-Gimenez, M. E., H. L. Ballard, and V. E. Sturtevant. 2008. Adaptive management and social learning in collaborative and communitybased monitoring: a study of five community-based forestry organizations in the western USA. Ecology and Society 13(2): 4. [online] URL: http://www.eco logyandsociety.org/vol13/iss2/art4/. 
Fernandez-Gimenez, M. E., H. P. Huntington, and K. J. Frost. 2006. Integration or cooptation? Traditional knowledge and science in the Alaska Beluga Whale Committee. Environmental Conservation 33(4):306-315.

Folke, C., F. Berkes, and J. Colding. 1998. Ecological practices and social mechanisms for building resilience and sustainability. Pages 414436 in F. Berkes and C. Folke, editors. Linking social and ecological systems: management practices and social mechanisms for building resilience. Cambridge University Press, Cambridge, UK.

Gadgil, M., F. Berkes, and C. Folke. 1993. Indigenous knowledge for biodiversity conservation. Ambio 22:151-156.

Gilchrist, G., and M. L. Mallory. 2007. Comparing expert-based science with local ecological knowledge: What are we afraid of? Ecology and Society 12(1): r1. [online] URL: http:/ /www.ecologyandsociety.org/vol12/iss1/resp1.

Gilchrist, G., M. Mallory, and F. Merkel. 2005. Can local ecological knowledge contribute to wildlife management? Case studies of migratory birds. Ecology and Society 10(1): 20. [online] URL: http://www.ecologyandsociety.org/vol10/iss1/art20/

Gray, G. J., M. J. Enzer, and J. Kusel, editors. 2001. Understanding community-based forest ecosystem management. Food Products Press, New York, New York, USA.

Holling, C. S. 1978. Adaptive environmental assessment and management. Wiley, Toronto, Ontario, Canada.

Huntington, H. P. 2000. Using traditional ecological knowledge in science: methods and applications. Ecological Applications 10(5):12701274.

Johannes, R. E. 1998. The case for data-less marine resource management: examples from tropical nearshore fisheries. Trends in Ecology and Evolution 13:243--246.

Klooster, D. J. 2002. Toward adaptive community forest management: integrating local forest knowledge with scientific forestry. Economic
Geography 78(1):43-70.

Kofinas, G. P. 2005. Caribou hunters and researchers at the co-management interface: emergent dilemmas and the dynamics of legitimacy in power sharing. Anthropologica 47:179-196.

Lee, K. N. 1993. Compass and gyroscope: integrating science and politics for the environment. Island Press, Washington, D.C., USA.

Mackinson, S. 2001. Integrating local and scientific knowledge: an example in fisheries science. Environmental Management 27(4):533-545.

Mallory, M. L., H. G. Gilchrist, A. J. Fontaine, and J. A. Akearok. 2003. Local ecological knowledge of ivory gull declines in Arctic Canada. Arctic 56(3):293-298.

Moller, H., F. Berkes, L. P. O'Brian, and M. Kislalioglu. 2004. Combining science and traditional ecological knowledge: monitoring populations for co-management. Ecology and Society 9(3): 2. [online] URL: http://www.ecologya ndsociety.org/vol9/iss3/art2.

Murphree, M. W. 2004. Communal approaches to natural resource management in Africa: from whence and to where? Journal of International Wildlife and Policy 7(3/4):203-216.

Nadasdy, P. 1999. The politics of TEK: power and "integration" of knowledge. Arctic Anthropology 36 (1/2):1-18.

Nadasdy, P. 2003. Re-evaluating the comanagement success story. Arctic 56(4):367-380.

Olsson, P., and C. Folke. 2001. Local ecological knowledge and institutional dynamics for ecosystem management: a study of Lake Racken Watershed, Sweden. Ecosystems 4(2):85-104.

Pattengill-Semmens, C. V., and B. X. Semmens. 2003. Conservation and management applications of the reef volunteer fish monitoring program. Environmental Monitoring and Assessment 81 $(1 / 3): 43-50$.

Pierotti, R., and D. Wildcat. 2000. Traditional ecological knowledge: the third alternative (commentary). Ecological Applications 10(5):13331340 . 
Scoones, I. 1999. New ecology and social sciences: what prospects for a fruitful engagement? Annual Review of Anthropology 28:479-507.

Schultz L., C. Folke, and P. Olsson. 2007. Enhancing ecosystem management through socialecological inventories: lessons from Kristianstads Vattenrike, Sweden. Environmental Conservation 34(2):140-152.

Shannon, M. A., and A. R. Antypas. 1996. Civic science is democracy in action. Northwest Science 70(1):66-69.

Sillitoe, P. 1998. The development of indigenous knowledge: a new applied anthropology. Current Anthropology 39(2):223-252.

Stevenson, M. G. 1996. Indigenous knowledge in environmental assessment. Arctic 49(3): 278-291.

Ticktin, T., and T. Johns. 2002. Chinanteco management of Aechmea magdalenae: implications for the use of TEK and TRM in management plans. Economic Botany 56(2):177-191.

Usher, P.J. 2000. Traditional ecological knowledge in environmental assessment and management. Arctic 53(2): 183-193.

Wilson, D. C., J. Raakjaer, and P. Degnbol. 2006. Local ecological knowledge and practical fisheries management in the tropics: a policy brief. Marine Policy 30:794-801.

Wondolleck, J. M., and S. L. Yaffee. 2000. Making collaboration work: lessons from innovation in natural resource management. Island Press, Washington, D.C., USA. 